\title{
Interpretation of Poetry through Drama Activities
}

Milena Vodickova

\begin{abstract}
This article will demonstrate how an effective lesson in poetry, which frequently frightens young people or to which they have a hostile attitude, can instead appeal to them. It is only important to choose the right text and the right method. In the lesson described in this article, students interpreted a poem through drama activities, and performing the roles of the characters enabled them to relax and provided them with more opportunities to speak English than in regular literature lessons. As the students found the lesson interesting and thought that teenagers could also enjoy it, this approach can be considered as an inspiration for their future career.
\end{abstract}

Key words: role-play, teacher-in-role, hot seating, still image

\section{Introduction}

The political changes in 1989 and, later on, the entrance of the Czech Republic in the European Union led to a growing interest in learning foreign languages. As a result, English has become the main foreign language in Czech schools (before 1989 it was Russian) and according to the law Czech children must start learning English in the third grade, which means at the age of 8 or 9, though some schools already provide obligatory English lessons from the first grade. In spite of many years of learning English, Czech citizens often feel that they are still not well prepared to communicate successfully in English, which is important nowadays in both professional and personal life. For this reason, the Czech media have recently launched a discussion about the main reasons for this unsatisfactory state, in which it is possible to hear the critical voices of learners who often miss a more communicative approach and complain of experiencing boredom in lessons.

It is the task of teachers to motivate their students and make their lessons as interesting as possible, and that is why it is not enough to use good textbooks, but also some entertaining activities which are based on supplementary materials. Therefore, many dedicated English teachers attend various seminars organized either by the British Council or publishing houses and universities, which supply them with some new ideas. Naturally, it is also the responsibility of faculties of education preparing future teachers to provide them with methods that will enliven their teaching. In that context, this article describes a literature lesson at the Faculty of Education at Palacky University in Olomouc (Czech Republic) in which students interpreted a poem through drama activities. Although poetry is not very popular among students, this approach to literature made students feel that dealing with poetry can be fun and that is why the lesson they enjoyed can serve for them as inspiration for their future teaching career.

\section{Interpretation of Poetry}

Cockett and Fox (1999: 83) emphasize the emotional character of poetry, which is frequently neglected in schools at the expense of its intellectual aspects. They suppose that the negative attitude of students 
towards poetry is caused by the way teachers deal with poetry in lessons in which they force students to analyse poetry without providing them with an opportunity to enjoy poems emotionally. In some poetry lessons students are expected to passively accept the ideas and views of literary critics, which would never occur to them.

This problem can be solved with a tolerant approach to readers when their interpretations of the text differ from the "official" views. In particular, the reader response theory of Louise Rosenblatt and Wolfgang Iser rejects the opinion that every literary text has only one fixed meaning and emphasises the importance of the role of the reader as the interpreter of the text (McManus, 1998). This tolerant approach to the interpretation of poetry gives students a lot of freedom to express their own views, and it is especially important in foreign language lessons, when students feel inhibited not only by the difficulties that poetry can present, but also by expressing their thoughts in the foreign language. For this reason, it is important to use methods which make students enjoy lessons and select poems that deal with problems that young people encounter and understand. In particular, narrative poems which contain a conflict or a topic of loneliness, refusal, or a complicated relationship are very suitable because they enable students to appear in situations in which they must solve conflicts and think about relationships with people. And it is drama activities that enable them to identify with the characters and to act like them, which leads to some genuine communication.

\section{Choice of Poetry}

The appeal of poetry lies in its ability to depict various human problems and crises in a succinct form, in bringing about surprising revelation, and leading to deep emotional experiences. The poem chosen for the lesson was What has happened to Lulu by Charles Causley (In Maley, A. and Moulding S. 1985: 27). It is a simple poem which tells the story of a young girl named Lulu who left home secretly at night. The speaker is Lulu's younger sibling, who does not understand the situation, but the mother refuses to explain anything. It is clear that there was an argument between the mother and Lulu. She was met by her boyfriend, who waited for her outside the house. The mother is at a loss as to what to do and tries to protect the younger brother/sister from that knowledge.

The poem was not only read and discussed, which is usually done in literature lessons, but, because this topic requires students' emotional participation, and instead the elements of structured drama were employed.

\section{Structuring of Drama Activities}

As drama is a fictional form which involves characters facing problems and getting into conflicts, it resembles real-life situations in which students might appear themselves. Acting in these situations provides them with the chance to get emotionally involved in the problems of other people and to try out what it is like to be somebody else. Acting as other characters is like putting on masks, which makes it easier for the "actors" to speak and act. As Neelands (1999: 3) states, "the experience of theatre is distinguished from real-life experience by the conscious application of form to meaning in order to engage both the intellect and the emotions in a representation of meaning. In the theatre, meanings, social codes and interactions are presented, shaped and crafted through the conventions of dramatic activity." Theatre is a learning medium where people experience the kind of behaviour in which they imagine that they are somebody else in a different place at a different time, which stimulates their creative imaginative behaviour. They can find in theatre a mirror that reflects their own behaviour and their reactions to others. This can be exploited in the seminars when students are expected to interpret human behaviour and be involved both intellectually and emotionally. As structured drama leads to an active exploration of a text and its meaning, the effectiveness of education in exploiting it depends directly on the dynamic structuring of the drama activities (called conventions) prepared by the teacher beforehand.

Conventions represent the approaches used in the exploration and creation of character and can emphasize various qualities in the theatrical possibilities of time, space and human behaviour. Some of the conventions, such 
as Portraits, Diaries, and Still Image, can set the scene or add some information to the context of the story. As drama is a human story, it is necessary to use conventions that contribute to narrating the action and can create and promote interest in the drama, such as Meetings, Hot-Seating, a Day in the Life, Teacher-in-Role. Some conventions can provide visual images, for example Still Image or Mimed Activity, while others emphasize verbal communication, such as Role-Play or Teacher-inRole.

\section{Description of Structured Drama}

Before the article describes how the abovementioned conventions were exploited in practice in the seminar, their explanation will be provided beforehand.

Portraits: pictures or photographs of characters provide students with a visual representation of the characters and with an opportunity to speculate about their human characteristics and their behaviour. Students are usually guided by the teacher's questions, which lead to a deeper understanding of the complexity of the characters.

Diary: Writing-in-Role: students in the role of a character write a diary in which they reflect on the character's experience.

Still Image: this is a convention in which participants co-operate in order to express the main concept in the form of an image using their bodies like a sculpture. This crystallizes a moment, an idea or a theme and represents the most important elements of the story at a particular moment. It has the same function as an illustration in a book, which usually focuses on the key moments of the story. While the students are preparing the still image, they must negotiate, which encourages a lot of speaking in the target language. As Neelands (1999: 19) states, it is "a very economical and controlled form of expression as well as a sign to be interpreted or read by observers,...it simplifies complex content into easily managed and understandable form, requires reflection and analysis in the making and observing images."
Meetings: students meet within the drama to make collective decisions and suggest strategies to solve problems, which moves the action forward.

Hot-Seating: Neelands (1999) describes this convention as an interview in which a group of students question a role-player who remains "in character". It provides insights into the personality, motivation and behaviour of the character.

A Day in the Life is a convention which emphasizes the narrative action. It is like a photograph which portrays characters at important moments of their life. "This convention works backwards from an important event in order to fill the gaps in the history of how the characters have arrived at the event" (Neelands, 1999: 27). It draws attention to the influences and the forces driving the characters to a conflict or their decisions. It clarifies the inner conflicts that are responsible for the events in the narrative.

Teacher-in-Role: this convention provides the teacher with an opportunity to act as a facilitator and to control the whole action. S/he is responsible for the interaction of the whole group within the context of the play, and s/he takes on the role of one of the characters while the students in the group also negotiate in the role of another character (Studentsin-Role). The teacher does not act spontaneously, but challenges students to interact with him/her by provoking their responses. As they are expected to react and express the opinions as if they were one of the characters of the play, it deepens their understanding of both the inner and outer conflicts presented in the story.

\section{Description of the Lesson}

Level: the poem, because of its simple language, can be used with intermediate students and an appropriate age is $14+$.

Time: to perform all the suggested drama activities with intermediate students might require a relatively long time, but it is possible to deal with them in several shorter parts by using only one or a few of them in different lessons, or to do everything as a one-day workshop. 
Language learning aims:

Reading: the poem

Speaking: asking questions, describing characters and their appearance, life experience, problemsworries, wishes and plans.

Writing: suggested writing tasks:

Lulu's short message to her mother;

a description of Lulu's appearance (for the police);

a report on Lulu's case written by a social worker (formal style);

a magazine article: Lulu's story (in a style appropriate to either the quality press or the popular press);

an entry in Lulu's diary (personal style).

Materials

A copy of the poem What Has Happened to Lulu. (Maley and Moulding, 1991: 27)

A picture of Lulu (a photograph of a teenage girl)

Samples of articles that demonstrate the style typical either of the quality or popular press.

\section{Activities Used in the Lesson}

Silent Reading

Students read the poem on their own and then the unknown vocabulary was explained (rag-doll, flap, crumple, gust of rain).

Several questions were asked to brainstorm some ideas about the characters and the situation.

Who is talking?

What can we deduce about the family?

Identify the characters in the poem and their problems.

What are the ages of Lulu and her sister or brother?

Why did Lulu leave home? What is her relationship to her mother? What is the mother's attitude to Lulu's behaviour? What can the mother do?

Does their father live with them?

Students in Role
In the role of Lulu, students wrote a message for her mother.

Group WorkStudents were divided in two groups: one of the groups played police officers and the other Lulu's mother. The students in the role of the police officers prepared questions that they could ask Lulu's mother. The students in the role of the mothers prepared a description of Lulu and had to be able to explain what had happened to her.

Role-play

This activity was performed in pairs, in which a police officer talked to the mother. This was a roleplay in which the mother was at the police station and was reporting that Lulu was missing. The police officer asked questions, which the mother answered. She also received a form that she had to fill in. (This written task can be done by all the students before the role play as it can help them with the conversation.)

\section{Diary: Writing in Role}

All the students (in the role of Lulu) wrote an entry in Lulu's diary. This was a description of what had happened and in it Lulu expressed her feelings. (This might be done as homework.)

\section{Still Image}

The students were divided into groups and each group prepared a few still images depicting some crucial moments from the night when Lulu left home. (This activity can be developed into a Day in the Life as it can demonstrate some events that preceded the dramatic decision of Lulu to leave home.)

\section{Hot-seating}

Hot-seating involves taking a person out of a dramatic fictional situation and placing him/her in the hot seat so that $\mathrm{s} /$ he may be questioned about events in the story, about his/her feelings, thoughts, etc. The characters who appeared in the hot seat were: Lulu, her mother, her sister or brother (who is very naïve), possibly her father, who does not live with them (or her stepfather), and also her boyfriend, who waited for her. The previous experience showed 
that teenage students usually identified with Lulu, and did not accept the fact that Lulu's mother was unhappy and worried about her daughter, and that is why a rule was made that the character had to stay in the role from the point where $\mathrm{s} /$ he entered the hot seat. On no account was the character allowed to slip out of the role and to speak as him/herself. Hot-seating is a story-building exercise and that is why it was emphasised that the questioners should avoid tricky questions and should collaborate rather than interrogate.

\section{Meeting}

The students got together (when the class is large, they can work in groups) and, through discussion, they tried to find some solution to the problem. They suggested what the individual characters should do to improve the situation.

\section{Writing activities}

The homework that resulted from the lesson was to write a newspaper article which could appear either in the quality press as a general treatment of the problem of teenage girls who run away from home (in a formal style) or in a tabloid (in an informal style). It could also be a report on Lulu's case written by a social worker (in a formal style).

\section{Students' Evaluation of the Lesson}

In the discussion that followed the students assessed the lesson very positively because speaking in roles provided them with more opportunities to use the English language than in other literature lessons, and they felt more relaxed. Most of them considered this lesson as an inspiration for their own lessons in their future teaching career. They also appreciated that the activities enabled them to move around in the classroom, which, after sitting for the whole morning, was very pleasant. Another important aspect of using drama activities was that they had to cooperate and appearing in roles taught them empathy, which, as they admitted, they will need as teachers.

\section{Guidelines for Teachers}

If students only read poetry, their approach to it is often superficial and they might not notice important aspects that are hidden between the lines. When they are required to enter the roles of the characters, they have to think about the motivation of the human actions that caused the situation. They must realize how the individual characters were affected by the behaviour of the others or they can speculate which other characters might have influenced the event. In the roles the students face a situation which releases emotions in them; however, they often do not feel like discussing such emotional issues in front of the whole class, and that is why it is recommended to use the intimacy of a small group or a pair, which drama activities often provide.

The term drama sometimes intimidates teachers because they think that it is a performance that they are expected to prepare. Drama activities in the classroom are, however, very useful because they require active participation from all the students, which means that everybody is an actor and also an observer at the same time. That is why it is important for everybody to understand that when doing drama nobody is expected to perform anything in front of anyone else.

The responsibility of the teacher is not only to structure all the drama activities, but the students must be prepared for them, and especially to become familiar with dramatic conventions, which can be seen as "a bridge between spontaneous and innate uses of theatre and the more poetic conventions of performance act" (ibid. p.5).

My preparation as a teacher was quite demanding as it was my responsibility to take the students through the crucial moments of the story. In the lesson I worked rather like a storyteller, creating the scene, painting pictures of the characters, and suggesting action, but leaving space for the students' imagination. I could not behave as an authority figure, but only an advisor, and had to ensure that there was a friendly atmosphere of trust and cooperation. The reward for me was that the students spoke freely and learnt how to behave in situations in which they might appear outside the classroom. 
Milena Vodickova teaches British and children's literature at the Faculty of Education, Palacky University in Olomouc, Czech Republic. Her areas of interest include drama activities in teaching children.

\section{References}

Kotátková S., et al. (1999). Vybrané kapitoly z dramatické výchovy. Praha: Karolinum.

McManus, B.F. (1998). Readings and assignments. Retrieved on January 18, 2010 from Reader-
Response Criticism http://www2.cnr.edu/home/ bmcmanus/readercrit.html.

Maley, A. \& Moulding, S. (1991). Poem into poem. Cambridge: Cambridge University Press.

Neelands, J. (1999). Structuring drama work. Cambridge: Cambridge University Press. 